\title{
COLONIZATION ABILITY OF ESCHERICHIA COLI AND LISTERIA MONOCYTOGENES IN THE ENDOSPHERE OF SWEET PEPPER (CAPSICUM ANNUUM VAR. GROSSUM)
}

\author{
Z. Füstös ${ }^{\mathrm{a}}, \mathrm{A}$. BeLÁK ${ }^{\mathrm{b}}$ and A. MARÁZz ${ }^{\mathrm{b} *}$ \\ ${ }^{a}$ Department of Nutritional Physiology, Food Science Research Institute, National Agricultural Research and \\ Innovation Center, H-1022 Budapest, Herman Ottó út 15. Hungary \\ ${ }^{b}$ Department of Microbiology and Biotechnology, Faculty of Food Science, Szent István University, H-1118 \\ Budapest, Somlói út 14-16. Hungary
}

(Received: 30 January 2017; accepted: 4 May 2017)

Fruits and vegetables can be transmission vehicles of human opportunistic and obligate pathogenic bacteria, persisting in inner tissues for shorter or longer periods or colonizing the plants as facultative endophytes. In this study we investigated the ability of commensal E. coli and pathogenic L. monocytogenes strains to internalize sweet pepper seedlings via seed bacterization, as germinating seeds and roots are important infiltration sites for entry of enteric bacteria. By combining cultivation dependent and independent (PCR and FISH-CLSM) techniques we could not detect stably or transiently colonized inoculated bacteria in 6-7 weeks old pepper seedlings, suggesting that there is low risk associated with internalized enteric or human pathogenic bacteria via germinating seeds in sweet pepper.

Keywords: Escherichia coli, Listeria monocytogenes, sweet pepper, internalization

Currently, in the background of high and increasing incidence of illnesses associated with consumption of fresh fruits and vegetables, there were defined bacterial human pathogens (Teplitski et al., 2009; Mendes et al., 2013; Martínez-Vaz et al., 2014; Van Overbeek et al., 2014). It is now an evidence that fruits and vegetables can be the transmission vehicles of some human pathogenic bacteria living inside plants as facultative endophytes (HALLMANN \& BERG, 2006; BERGER et al., 2010). Recently VAN OVERBEeK and co-workers (2014) suggested to use the term "phytonosis" for the transmission of otherwise zoonotic human pathogenic bacteria via plants.

Foodborne pathogenic bacteria can internalize the plants either preharvest or postharvest through uninjured or damaged plant tissues (stomata, hydathodes, trichomes or leaf tip burn lesions, disrupted plant cuticle, crevices, respectively). Germinating seeds and roots are also considered as important infiltration sites; lateral root junctions are the "hot spots" for entry of enteric pathogens (Mendes et al., 2013). Fate of the internalized cells depends on the persistence and colonization within the plant tissues, what is highly influenced by the interaction with the native plant-associated microbiota. TYLER and TRIPLETT (2008) hypothesized that plants may serve as alternative hosts for certain human pathogenic bacteria for surviving the unfavourable environmental conditions, and during animal ingestion they are released for re-colonizing the original host.

Enteric pathogens comprising different Salmonella enterica serovars and pathogenic E. coli strains were responsible for outbreaks associated with the consumption of fresh vegetables and fruit in most cases, but less frequently Shigella, Campylobacter spp., Yersinia

\footnotetext{
* To whom correspondence should be addressed.

Phone: +36-1-305-7009; fax: +36-1-305-7340; e-mail: maraz.anna@etk.szie.hu
} 
enterocolitica, Clostridium botulinum, Vibrio cholerae, L. monocytogenes, and Staphylococcus aureus were also involved (WARRINER, 2005; BECZNER \& BATA-VIDÁCS, 2009; BERGER et al., 2010; CDC, 2013a, 2013b).

MARTínez-VAZ and co-workers (2014) referred to different pathogenic E. coli serotypes and Salmonella enterica serovars as identified causative agents of outbreaks, initiated by the consumption of leafy greens and sprouts between 2006 and 2012.

Enteric pathogens, especially those belonging to the family Enterobacteriaceae, get into contact with roots, stems, leaves, fruit, and seeds of cultivated plants from the environment via water, soil, raw or inadequately amended manure (MARTínEz-VAZ et al., 2014; VAN OverbeEK et al., 2014). Enteric bacteria, especially Salmonella and E. coli O157:H7 have enough survival capacity in soil to contaminate plants and adapt to the plant environment (TEPLITSKI et al., 2009; Berger et al., 2010; MARTínez-VAz et al., 2014).

L. monocytogenes is an important Gram-positive foodborne pathogen, although $L$. monocytogenes infections are much more rarely associated with consumption of plantderived foods than that of the dairy and meat products. L. monocytogenes is a highly tolerant and adaptive pathogenic bacterium (BRANDL, 2006) being present in many environmental niches like soil, water, and plants (VIVANT et al., 2013). Domesticated animals can carry the pathogen without any symptoms of infection and may contaminate milk and meat. Transmission of $L$. monocytogenes from farm animals to fruits and vegetables can take place via manure used for fertilization. Contaminated soil could be an effective mediator, as $L$. monocytogenes has a long survival time in soil at a wide range of temperatures (JIANG et al., 2004).

Difficulty in the identification of $L$. monocytogenes as causative agent of foodborne outbreaks could be attributed to the fact that a high ratio of listeriosis is sporadic, what could be ascribed to the long incubation period of the illness (Milillo et al., 2008). A systematic analysis of listeriosis in the USA between 2000 and 2003 (VARMA et al., 2007) supported the sporadic nature of listeriosis and revealed that $L$. monocytogenes infections were associated with the consumption of commercially produced melons and hummus in this period. Centers for Disease Control and Prevention (CDC (2016)) reported recently that frozen vegetables were responsible for an outbreak in the USA. PALMAI and Buchanan (2002) demonstrated that $L$. monocytogenes was able to proliferate during germination of alfalfa sprouts and survived at a constant level at refrigeration temperature for seven days. Another food safety risk comes from the induction of a metabolically arrested, viable but non-culturable (VBNC) state of both E. coli and L. monocytogenes cells under stressful conditions (Dreux et al., 2007; DinU \& BACH, 2011).

In our studies we intended to check whether non-pathogenic (commensal) E. coli and foodborne human pathogenic $L$. monocytogenes strains are able to infiltrate and colonize sweet pepper via seed inoculation under similar conditions as the endophytic bacteria internalize host plants.

\section{Materials and methods}

\subsection{Strains, culture conditions, and maintenance}

E. coli ATCC 8739, L. monocytogenes CCM 4699, L. innocua 1010, and L. grayi CCM 4029 were used in the experiments, which were maintained in PGYS (peptone $5 \mathrm{~g} \mathrm{l}^{-1}$; glucose $1 \mathrm{~g} \mathrm{l}^{-1}$; yeast extract $2.5 \mathrm{~g} \mathrm{l}^{-1}, \mathrm{NaCl} 5 \mathrm{~g} \mathrm{l}^{-1}$ ) agar at $4^{\circ} \mathrm{C}$. 


\subsection{Pepper seed bacterization, plant breeding, and sample processing}

Seeds of Karpia cultivar of sweet pepper (Capsicum annuum L. var. grossum) were surfacedisinfected (BELÁK et al., 2014) and inoculated with E. coli ATCC 8739 and L. monocytogenes CCM 4699 separately, as described in NIRANJAN RAJ and co-workers (2003). Non-inoculated seeds served as sterile controls, while non-disinfected ones without bacterization were used as non-sterile controls. Seed germination was a slightly modified version of the paper towel method according to the International Seed Testing Association protocol (ISTA, 2016).

After seed germination, 9 seedlings with two cotyledons were selected from each of the bacterized and control samples, planted to rock wool cubes and cultivated in beakers under aseptic condition. Rock wool cubes were moisturized with $1.2 \mathrm{~g} \mathrm{l}^{-1}$ Ferticare ${ }^{\mathrm{TM}} \mathrm{I}$ fertilizer and seedlings were irrigated with $2.2 \mathrm{~g} \mathrm{l}^{-1}$ of this solution. Phytolite Agro Grow-Bloom HPS 400 W lamp (PHT Trading SA, Ticino, Switzerland) supplied adequate light for indoor cultivation for 35-40 days.

\subsection{Detection of the inoculated bacteria in the endosphere of pepper seedlings}

After the cultivation process 9 seedlings (those from the bacterized and control samples) were divided into 3 equal groups and treated as follows.

1.3.1. Cultivation of bacteria from different organs of the seedlings. Small pieces of tissue samples were placed onto Chromocult ${ }^{\circledR}$ coliform (Merck KGaA, Darmstadt, Germany) and Listeria selective ALOA (Microgen Bioproducts Ltd., Camberley, UK) agar media, respectively, and incubated for 5 days at $30{ }^{\circ} \mathrm{C}$.

1.3.2. Direct amplification of bacterial DNA by PCR. Plant tissue samples were homogenized in 1x PBS buffer (DAIMs et al., 2005) by IKA Ultra Turrax ${ }^{\circledR}$ T25 (IKA® Werke GmbH \& Co. KG, Staufen, Germany). DNA was isolated with the PowerSoil ${ }^{\circledR}$ Pro DNA Isolation Kit (MO BIO Laboratories, Qiagen, Carlsbad, USA). Specific PCR reactions were applied to detect strains used for seed bacterization (Table 1).

\begin{tabular}{|c|c|c|c|c|c|}
\hline Target/specificity & $\begin{array}{l}\text { Primer } \\
\text { name }\end{array}$ & Primer sequence $5^{\prime} \rightarrow 3^{\prime}$ & $\begin{array}{l}\text { AS } \\
\text { bp }\end{array}$ & $\begin{array}{l}\mathrm{AT} \\
{ }^{\circ} \mathrm{C} \\
\end{array}$ & References \\
\hline $\begin{array}{l}6 \mathrm{~S} \text { rDNA/all } \\
\text { acteria }\end{array}$ & $\begin{array}{l}27 f \\
1492 r\end{array}$ & $\begin{array}{l}\text { AGAGTTTGATCMTGGCTCAG } \\
\text { TACGGYTACCTTGTTACGACTT }\end{array}$ & 1467 & 58 & $\begin{array}{l}\text { EDWARDS et al., } \\
\text { 1989; WEISBURG et }\end{array}$ \\
\hline $\begin{array}{l}16 \mathrm{~S} \text { rDNA/all } \\
\text { pacteria }\end{array}$ & $\begin{array}{l}1070 \mathrm{f} \\
1492 \mathrm{r}\end{array}$ & $\begin{array}{l}\text { TCAGCTCGTGTYGTGARA } \\
\text { TACGGYTACCTTGTTACGACTT }\end{array}$ & $\begin{array}{c}448 \\
(863)\end{array}$ & 52 & $\begin{array}{l}\text { al., } 1991 \\
\text { SHAKYA et al., 2013; }\end{array}$ \\
\hline $\begin{array}{l}\text { 16S rDNA/ } \\
\text { Listeria }\end{array}$ & $\begin{array}{l}27 f \\
\text { Lis659R }\end{array}$ & $\begin{array}{l}\text { AGAGTTTGATCMTGGCTCAG } \\
\text { CACTCCAGTCTTCCAGTTTC }\end{array}$ & 659 & 68 & Lis659R: this work \\
\hline $\begin{array}{l}\text { 16S rDNA/E. coli } \\
\text { and Shigella }\end{array}$ & $\begin{array}{l}27 f \\
\text { Ec/Sh473R }\end{array}$ & $\begin{array}{l}\text { AGAGTTTGATCMTGGCTCAG } \\
\text { AAAGGTATTAACTTTACTCCCT }\end{array}$ & 466 & & $\begin{array}{l}\text { Ec/Sh473R: this } \\
\text { work }\end{array}$ \\
\hline
\end{tabular}

Nucleotides marked bold indicate degeneracy. M: A or C; R: A or G; Y: C or T

1.3.3. Detection of the colonized bacteria by FISH-CLSM. Plant organs were sliced into $10-15 \mathrm{~mm}$ long pieces and treated with a fixative solution (4\% formaldehyde in $1 \mathrm{x}$ PBS) overnight at $4{ }^{\circ} \mathrm{C}$. After fixation, samples were rinsed three times in $1 \mathrm{x}$ PBS and stored in a solution containing $1 \times \mathrm{PBS}$ and $96 \%$ ethanol $(1: 1)$ at $-20^{\circ} \mathrm{C}$. For specimen preparation, fixed 
samples were embedded into Shandon ${ }^{\mathrm{TM}}$ Cryomatrix ${ }^{\mathrm{TM}}$ (Thermo Fisher Scientific Inc., Waltham, USA) solution at $-23{ }^{\circ} \mathrm{C}$ for 20 min, sliced into $10-20 \mu \mathrm{m}$ thick sections with Microm HM 505 NP Cryostat Microtome (MICROM International GmbH, Walldorf, Germany) and were placed onto microscopic slides. Citiflour AF1 (Citifluor Ltd., London, UK) was used as antifadent mounting agent. FISH analysis was performed as described by DAIMS and co-workers (2005). Image capturing was performed with Zeiss LSM 710 (Carl Zeiss AG, Oberkochen, Germany) confocal laser scanning microscope (CLSM).

\subsection{PCR analysis}

Oligonucleotide primers for PCR reactions were designed by aligning the 16S rDNA sequences of the targeted and the closest reference (mostly type) strains belonging to the same genus, using MEGA6 program (TAMURA et al., 2013). Characteristics of the PCR primer pairs (melting temperature, GC content, and chance for secondary structure formation) were evaluated by OligoAnalyzer 3.1 IDT SciTool program (Integrated DNA Technologies Inc.). For evaluation of the primer specificity, NCBI Nucleotide BLAST tool (i) was used (BLAST). PCR primers shown in Table 1 were applied for amplification of 16S rDNA as well as for detection of the seed-inoculated E. coli ATCC 8739 and L. monocytogenes CCM 4699 strains.

\subsection{Designing and testing of FISH probes}

New oligonucleotide probes based on the 16S rRNA gene sequences of the target strains were created by using the $\mathrm{ARB}^{\circ}$ 6.0.2 program package (LuDwIG et al., 2004). Specificity of FISH probes was tested by using the probeCheck web server (Loy et al., 2008), while thermodynamic properties of the probes (hybridization efficiency, change in Gibbs free energy, and the formamide dissociation profile) were evaluated by the mathFISH webtools (MATHFISH).

E. coli/Shigella-specific Ec/Sh_453 probe described by JANSEN and co-workers (2000) was adapted for labelling E. coli ATCC 8739 cells. Lis-637 probe for targeting L. monocytogenes CCM 4699 strain was selected for FISH analysis, which hybridizes to most Listeria species, except L. grayi (Schmid et al., 2003). However, because weak mismatching to some Peanibacillus and Bacillus strains was detected, competitive probe Lis-comp was also designed. Hybridization probes and conditions are shown in Table 2.

Table 2. FISH probes used in this work: sequences, labelling, and formamide (FA) concentrations

\begin{tabular}{|c|c|c|c|c|c|}
\hline $\begin{array}{l}\text { Specificity for } \\
\text { bacteria }\end{array}$ & $\begin{array}{l}\text { Probe } \\
\text { names }\end{array}$ & Sequences $5^{\prime} \rightarrow 3^{\prime}$ & $\begin{array}{l}5 \text { ' end } \\
\text { labelling }\end{array}$ & $\begin{array}{c}\text { FA } \\
\%\end{array}$ & References \\
\hline Most bacteria & EUB338 & GCTGCCTCCCGTAGGAGT & 6-FAM/Cy3 & $15-35$ & $\begin{array}{l}\text { AMANn et al., } \\
1990\end{array}$ \\
\hline Planctomycetales & EUB338 II & GCAGCCACCCGTAGGTGT & 6-FAM/Cy3 & $15-35$ & \\
\hline Verrucomicrobiales & EUB338 III & GCTGCCACCCGTAGGTGT & 6-FAM/Cy3 & $15-35$ & $\begin{array}{l}\text { DAIMS et al., } \\
1999\end{array}$ \\
\hline All bacteria & EUB mix & $\begin{array}{l}\text { EUB338 : EUB338II : EUB338 III = } \\
1: 1: 1\end{array}$ & 6-FAM/Cy3 & $15-35$ & $\begin{array}{l}\text { BATHE \& } \\
\text { HAUSNER, } 2006\end{array}$ \\
\hline $\begin{array}{l}\text { Listeria spp., } \\
\text { except } L \text {. grayi }\end{array}$ & Lis-637 & CACTCCAGTCTTCCAGTTTCC & 6-FAM & 35 & $\begin{array}{l}\text { SchмiD et al., } \\
2003\end{array}$ \\
\hline Listeria competitor & Lis-comp & CACTCCAGTCTCCCAGTTTCC & no labelling & 35 & This work \\
\hline E. coli/Shigella & $\mathrm{Ec} / \mathrm{Sh} \_453$ & GCAAAGGTATTAACTTTACTCCC & 6-FAM & 15 & $\begin{array}{l}\text { JANSEN et al., } \\
2000\end{array}$ \\
\hline
\end{tabular}


Combinatorial labelling with the application of EUB mix and specific probes was used for simultaneous detection of the inoculated (target) and natural endophytic (non-target) bacteria (Table 3).

Table 3. General and specific probes used for combinatorial labelling

\begin{tabular}{lll}
\hline Sample name & General probes $\rightarrow$ labelling & Specific probe $\rightarrow$ labelling \\
\hline L. monocytogenes - inoculated seedlings & EUB mix $\rightarrow$ Cy3 & Lis-637 $\rightarrow$ 6-FAM \\
& & Lis-comp \\
E. coli - inoculated seedlings & EUB mix $\rightarrow$ Cy3 & Ec/Sh_453 $\rightarrow$ 6-FAM \\
Sterile and non-sterile control seedlings & EUB mix $\rightarrow$ Cy3 & Lis-637 $\rightarrow$ 6-FAM \\
& & Lis-comp \\
& EUB mix $\rightarrow$ Cy3 & Ec/Sh_453 $\rightarrow$ 6-FAM \\
\hline
\end{tabular}

FISH test of bacterial pure cultures was implemented with suspensions of strains grown on PGYS agar for 24 hours. FISH-CLSM analysis was performed as described in section 1.3.

\section{Results and discussion}

\subsection{Infiltration of pepper seeds by E. coli and L. monocytogenes}

In order to analyse colonization ability of the commensal E. coli ATCC 8739 and the human pathogenic L. monocytogenes CCM 4699 strains, sweet pepper seeds were separately inoculated with these bacteria. Bacterized seeds germinated in good rate and seedlings had similar development to the control plants (grown from non-inoculated seeds) under aseptic conditions.

\subsection{Detection of seed inoculated bacteria in pepper seedlings by cultivation}

Persistence and colonization of seed-inoculated bacteria E. coli ATCC 8739 and L. monocytogenes CCM 4699 in sweet pepper were checked by incubating the plant organ samples (roots, stems, and leaves) on selective culture media.

Detection of any typical E. coli or L. monocytogenes colonies on coliform selective Chromocult ${ }^{\circledR}$ or Listeria selective ALOA agar media, respectively, gave negative results. This indicated that neither E. coli ATCC 8739 nor L. monocytogenes CCM 4699 were able to colonize plant tissues through seed bacterization.

\subsection{Detection of seed inoculated bacteria in pepper seedlings by direct amplification from the extracted DNA}

PCR amplification with species-specific primers was used in order to detect the presence of the inoculated bacterial strains in DNA extracted directly from the plant samples. For PCR detection of E. coli ATCC 8739 and L. monocytogenes CCM 4699 strains, 27f -Ec/Sh473R and 27f -Lis659R primer pairs were applied, respectively (Table 1). As shown in Figure 1, PCR detection of any E. coli and L. monocytogenes in DNA extracted from the inoculated 
pepper plants failed, which confirmed the negative results of the cultivation-based detection on selective media.

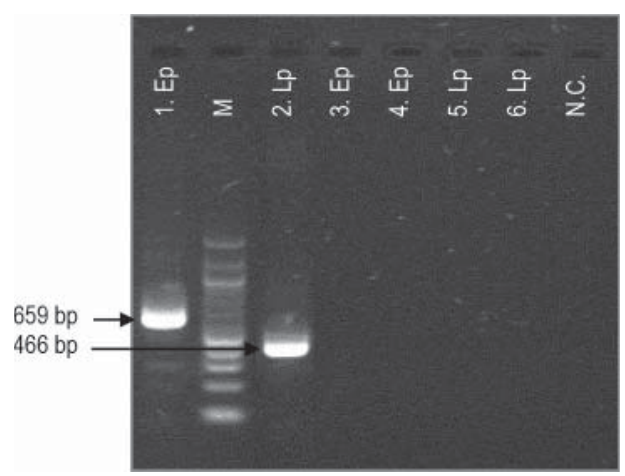

Fig. 1. PCR detection of E. coli ATCC 8739 and L. monocytogenes CCM 4699 in DNA extracted from pepper seedlings grown from inoculated seeds

1. Ep: PCR product of E. coli ATCC 8739; 2. Lp: PCR product of L. monocytogenes CCM 4699; 3. Ep: PCR detection of E. coli in root; 4. Ep: PCR detection of E. coli in shoot; 5. Lp PCR detection of L. monocytogenes in root; 6. Lp: PCR detection of L. monocytogenes in shoot

Legend: Ep: 27f, Ec/Sh473R primers; Lp: 27f, Lis659R primers; N.C.: negative control. M: 100 bp DNA ladder (100-1517 bp, Catalog \#: N3231S, New England Biolabs ${ }^{\circledR}$ Inc., USA)

\subsection{Detection of seed inoculated bacteria in the pepper seedlings by FISH-CLSM technique}

Visualization of seed-inoculated bacterial cells in the internal pepper tissues was performed by FISH-CLSM technique as described in Materials and methods. In FISH analysis general probes were used for detection of any kind of bacteria, while specific probes were applied in order to study the presence of bacteria used for seed bacterization (Table 3).

Hybridization efficiency of the E. coli/Shigella-specific Ec/Sh_453 probe (Table 2), as tested on the cells of $E$. coli ATCC 8739 under stringent condition, gave satisfactory result (Fig. 2), therefore it was used for targeting this strain in FISH-CLSM analysis.

Lis-637 probe also seemed to be suitable for detection of the inoculated L. monocytogenes strain by FISH-CLSM, as Lis-637 gave positive hybridization signal with cells of the tested species belonging to the Listeria genus, except $L$. grayi. In order to avoid false positive results as the consequence of potential mismatching of the probe, the competitive Lis-comp probe was used in combination with the Lis- 637 probe (Table 2). In silico FISH testing of the combined Lis-comp and Lis-637 probes resulted in strong fluorescence of $L$. monocytogenes and L. innocua but not L. grayi cells (Fig. 2). 


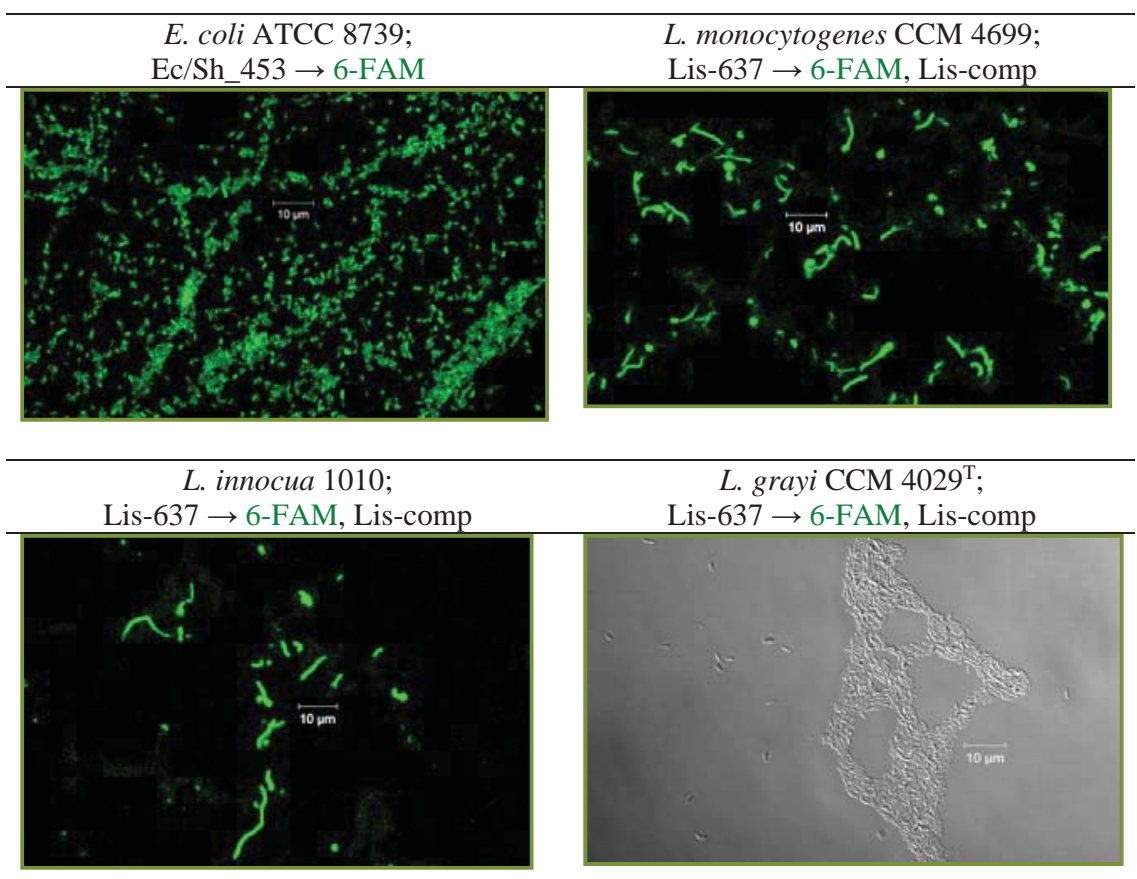

Fig. 2. Representative FISH-CLSM images of bacterial cells. Fluorescence of E. coli ATCC 8739 cells indicates hybridization with the Ec/Sh 453 probe, while fluorescence of L. monocytogenes CCM 4699 and L. innocua 1010 cells is the consequence of binding the Lis-637 probe. L. grayi CCM 4029 represents a negative control emitting no fluorescence. Probe legends: Probe name $\rightarrow$ labelling

Images of Fig. 3A illustrate that only a few red fluorescent cells appeared in plant sections (roots and shoots) inoculated with E. coli ATCC 8739. Red colour of the cells indicated hybridisation with the EUB mix probe alone, therefore these cells do not belong to E. coli, not even to the genera of Escherichia or Shigella. As shown in Fig. 3B, it was not possible to detect any bacterial cells in plant sections inoculated with $L$. monocytogenes CCM 4699. Seedlings grown up from non-inoculated, sterilized or non-sterilized (control) seeds were also analysed by hybridization with the combined EUB mix and specific probes. Results shown in Figures 3C and 3D indicate that no bacterial cells could be detected in most cases. There was only one root section of a pepper plant originated from sterilized seed (Fig. 3D), where a few cells emerged in the EUB mix emitting red colour. These cells probably belonged to the natural endophytic bacteriobiota and not to any of the bacterial strains used for seed inoculation. 

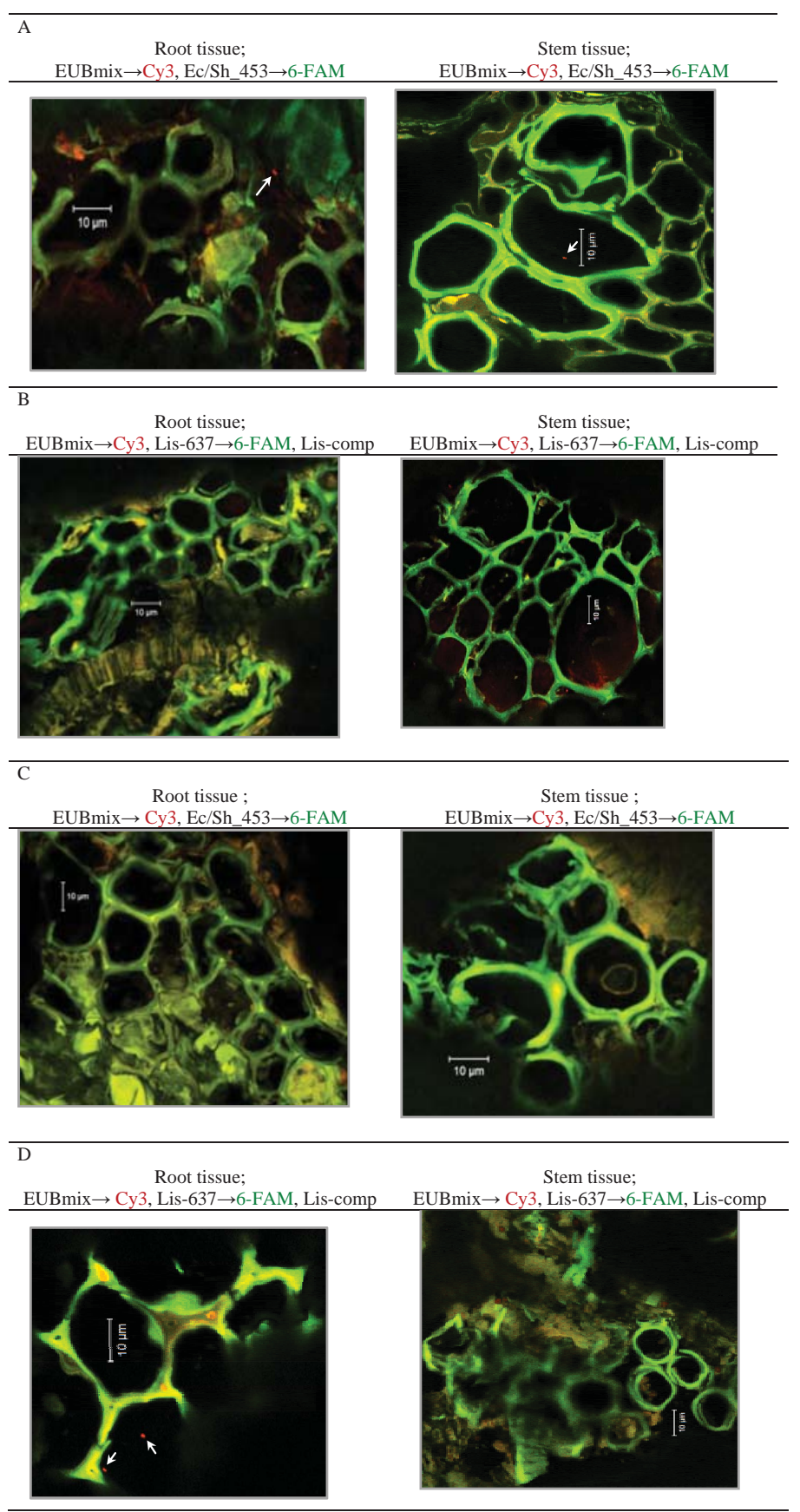

Fig. 3. Representative FISH-CLSM images of different tissue specimens prepared from inoculated and noninoculated (control) pepper seedlings. A: surface sterilized seeds were inoculated with E. coli ATCC 8739; B: surface sterilized seeds were inoculated with L. monocytogenes CCM 4699; C: seeds were not sterilized and not inoculated; D: surface sterilized seeds were not inoculated. Fluorescent cells are indicated by arrows. Probe legends: Probe name $\rightarrow$ labelling 
Absence of the inoculated bacterial cells in the endosphere could be explained by the incapability of the inoculated bacteria to infiltrate the seeds or migrate into the internal plant tissues. Even if internalization was successful, they were not able to survive plant cultivation period in an adequate amount to be detected by FISH-CLSM as it has a relatively high detection limit (approx. $10^{3}$ cells $\mathrm{ml}^{-1}$ or gram ${ }^{-1}$ ).

According to our results, the applied L. monocytogenes strain is unable to internalize sweet pepper seedlings. This is different from the results obtained by MiLILLO and co-workers (2008), who found that L. monocytogenes strains were able to attach to seeds and internalize intercellular spaces of the plant model Arabidopsis thaliana. In this case, although bacterization of the seeds considerably decreased seed germination frequency, $L$. monocytogenes was recovered from the leaves of plants originated from the inoculated seeds. Sweet pepper seems therefore more resistant to the infiltration by L. monocytogenes than $A$. thaliana. JABLASONE and co-workers (2005) reported that both L. monocytogenes and E. coli O157:H7 were able to establish and persist in young (9 days old) seedlings of several vegetables (carrot, cress, lettuce, radish, spinach, and tomato) but were not recovered from tissues of mature plants. Our results confirm their conclusion, emphasising that the risk associated with internalized human pathogenic bacteria at harvesting time is low.

Pathogenic and non-pathogenic (K-12) E. coli strains are using the same strategies in the first steps of interaction with plants (attachment by curli fibres and flagellae to the surface, suppression of biofilm formation, and a downward shift in the energy metabolism), as it was demonstrated by FinK and co-workers (2012), who compared the whole genome transcriptions by microarray analysis. Hou and co-workers (2012) came to similar conclusions, when they analysed colonization and growth of E. coli K-12 in the lettuce rhizosphere, by combining transcriptional analysis, colonization assays, and CLSM. Genes coding for the curli and flagellum synthesis were crucial in the attachment, and genes involved in protein synthesis and stress responses (biofilm modulation) were up-regulated. Dong and co-workers (2003) found differences among E. coli O157:H7 and K-12 strains in colonization of the rhizosphere and endosphere of alfalfa seedlings depending on the inoculum levels. However, colonization of the endosphere by K-12 was weak, independently of the inoculum levels, indicating that genotypes of $E$. coli strains have an influence on the internalization. Our results suggest that even if the non-pathogenic (commensal) E. coli was able to attach to sweet pepper seeds, colonization in the 6-7 weeks old seedlings could not be demonstrated by cultivation dependent and molecular techniques.

\section{Conclusions}

Seed bacterization and combination of cultivation dependent and independent (PCR and FISH-CLSM) techniques provide efficient tools for studying the infiltration, persistence, and colonization of harmless E. coli and foodborne pathogenic L. monocytogenes in sweet pepper, especially because hydroponic cultivation is becoming a more and more popular agrotechnique for this freshly consumed vegetable's production. Sweet pepper seems to be at low risk in this respect, because no stable colonization of the inoculated strains in the inner tissues could be demonstrated, not even a transient persistence could be suspected by PCR amplification of DNA being present in dead or VBNC cells. 
This work was funded by the Hungarian project OTKA K-101716. Ágnes Belák and Zoltán Füstös were supported through the "National Excellence Program" grants TÁMOP 4.2.4. A/-11-1-2012-0001 and TÁMOP4.2.4B/1-11/1-2012-0001, respectively.

\section{References}

Amann, R.I., Binder, B.J., Olson, R.J., Chisholm, S.W., DevereuX, R. \& Stahl, D.A. (1990): Combination of 16S rRNA-targeted oligonucleotide probes with flow cytometry for analyzing mixed microbial populations. Appl. Environ. Microb., 56, 1919-1925.

BATHE, S. \& HAUSNER, M. (2006): Design and evaluation of 16S rRNA sequence based oligonucleotide probes for the detection and quantification of Comamonas testosteroni in mixed microbial communities. BMC Microbiol., 6,54 .

Beczner, J. \& Bata-Vidécs, I. (2009): Microbiology of plant foods and related aspects. Acta Alimentaria, 38 (Suppl.), 99-115.

Belák, Á., HéHer, B., Füstös, Z., Kovács, M. \& Maráz, A. (2014): Endophytic bacteria from Capsicum annuum var. grossum cultivars and their inhibitory effects on Listeria monocytogenes. Acta Alimentaria, 43 (Suppl.), 9-20.

Berger, C.N., Sodha, S.V., Shaw, R.K., Griffin, P.M., Pink, D., Hand, P. \& Frankel, G. (2010): Fresh fruit and vegetables as vehicles for the transmission of human pathogens. Environ. Microbiol., 12, 2385-2397.

BLAST: http://blast.ncbi.nlm.nih.gov/Blast.cg. (last accessed 5 November 2016)

BrandL, M.T. (2006): Fitness of human enteric pathogens on plants and implications for food safety. Annu. Rev. Phytopathol., 44, 367-392.

CDC (2013a): Surveillance for foodborne disease outbreaks - United States, 1998-2008. MMWR; 62(3), 1-34.

CDC (2013b): Surveillance for foodborne disease outbreaks - United States, 2009-2010. MMWR; 62(3), 41-47.

CDC (2016): Multistate outbreak of listeriosis linked to frozen vegetables (Final Update). Available at http://www. cdc.gov/listeria/outbreaks/frozen-vegetables-05-16/index.html (last accessed 5 November 2016)

Daims, H., Bruhl, A., Amann, R., Schleifer, K.H. \& Wagner, M. (1999): The domain-specific probe EUB338 is insufficient for the detection of all bacteria: Development and evaluation of a more comprehensive probe set. Syst. Appl. Microbiol., 22, 434-444.

Daims, H., Stoecker, K. \& Wagner, M. (2005): Fluorescence in situ hybridization for the detection of prokaryotes. -in: OsBorn, A.M. \& Smith, C.J. (Eds) Advanced methods in molecular microbial ecology. Bios-Garland, Abingdon, pp. 213-239.

DiNu, L.-R. \& BACH, S. (2011): Induction of viable but nonculturable Escherichia coli O157:H7 in the phyllosphere of lettuce: a food safety risk factor. Appl. Environ. Microbiol., 77(23), 8295-8302.

Dong, Y., InIGuez, A.L., Ahmer, B.M.M. \& TRIPLETT, E.W. (2003): Kinetics and strain specificity of rhizosphere and endophytic colonization by enteric bacteria on seedlings of Medicago sativa and Medicago truncatula. Appl. Environ. Microbiol., 69(3), 1783-1790.

Dreux, N., Albagnac, C., Federighi, M., Carlin, F., Morris, C.E. \& Nguyen, C. (2007): Viable but non-culturable Listeria monocytogenes on parsley leaves and absence of recovery to a culturable state. J. Appl. Microbiol.. 103, 1272-1281.

Edwards, U., Rogall, T., Blocker, H., Emde, M. \& Bottger, E.C. (1989): Isolation and direct complete nucleotide determination of entire genes. Characterization of a gene coding for 16S ribosomal RNA. Nucleic Acids Res., $17,7843-7853$.

Fink, R.C., Black, E.P., Hou, Z., Sugawara, M., Sadowsky, M.J. \& Diez-Gonzalez, F. (2012): Transcriptional responses of Escherichia coli K-12 and O157:H7 associated with lettuce leaves. Appl. Environ. Microbiol., $78,1752-1764$.

Hallmann, J. \& Berg, G. (2006): Spectrum and population dynamics of bacterial root endophytes. -in: Schulz, B., Boyle, C. \& Sieber, T. (Eds) Microbial root endophytes. Springer SBM, Heidelberg, pp. 26-27.

Hou, Z., Fink, R.C., Black, E.P., Sugawara, M., Zhang, Z., Diez-Gonzalez, F. \& Sadowsky, M.J. (2012): Gene expression profiling of Escherichia coli in response to interactions with the lettuce rhizosphere. J. Appl. Microbiol., 113, 1076-1086.

INTEGRATED DNA TeChNOLOGIES Inc.: http://eu.idtdna.com/calc/analyzer. (last accessed 5 November 2016)

ISTA (2016). Сн. 5: The germination test. -in: International rules for seed testing. International Seed Testing Association, Bassersdorf, pp. i-5-56. 
Jablasone, J., Warriner, K. \& Griffiths, M. (2005): Interactions of Escherichia coli O157:H7, Salmonella typhimurium and Listeria monocytogenes plants cultivated in a gnotobiotic system. Int. J. Food Microbiol., 99, 7-18.

Jansen, G.J., Mooibroek, M., Idema, J., Harmsen, H.J., Welling, G.W. \& Degener, J.E. (2000): Rapid identification of bacteria in blood cultures by using fluorescently labeled oligonucleotide probes. J. Clin. Microbiol., 38, 814-817.

Jiang, X., Islam, M., Morgan, J. \& Doyle, M.P. (2004): Fate of Listeria monocytogenes in bovine manure-amended soil. J. Food Protect., 8, 1676-1681.

Loy, A., Arnold, R., Tishler, P., Rattei, T., Wagner, M. \& Horn, M. (2008): probeCheck - a central resource for evaluating oligonucleotide probe coverage and specificity. Environ. Microbiol., 10, 2894-2898.

Ludwig, W., Strunk, O., Westram, R., Richter, L., Meier, H., et al. (2004): ARB: a software environment for sequence data. Nucleic Acids Res., 32, 1363-1371.

Martínez-Vaz, B.M., Fink, R.C., Diez-Gonzalez, F. \& Sadowsky, M.J. (2014): Enteric pathogen-plant interactions: Molecular connections leading to colonization and growth and implications for food safety. Microbes Environ., 29(2), 123-135

MATHFISH: http://mathfish.cee.wisc.edu/ (last accessed 5 November 2016)

Mendes, R., Garbeva, P. \& RaAijmakers, J.M. (2013): The rhizosphere microbiome: significance of plant beneficial, plant pathogenic, and human pathogenic microorganisms. FEMS Microbiol. Rev., 37, 634-663.

Milillo, S.R., Badamo, J.M., Boor, K.J. \& Wiedmann, M. (2008): Growth and persistence of Listeria monocytogenes isolates on the plant model Arabidopsis thaliana. Food Microbiol., 25, 698-704.

Niranjan Raj, S., Chaluvaraju, G., Amruthesh, K.N., Shetty, H.S., Reddy, M.S. \& Kloepper, J.W. (2003): Induction of growth promotion and resistance against downy mildew on pearl millet (Pennisetum glaucum) by rhizobacteria. Plant Dis., 87, 380-384.

Palmai, M. \& Buchanan, R.L. (2002): Growth of Listeria monocytogenes during germination of alfalfa sprouts. Food Microbiol., 19, 195-200.

Schmid, M., Walcher, M., Bubert, A., Wagner, M., Wagner, M. \& Schleifer, K.H. (2003): Nucleic acid-based, cultivation-independent detection of Listeria spp and genotypes of L. monocytogenes. FEMS Immunol. Med. Mic., 35, 215-225.

Shakya, M., Gottel, N., Castro, H., Yang, Z.K., Gunter, L., Labbe, J., Muchero, W., Bonito, G., Vilgalys, R., Tuskan, G., Podar, M. \& Schadt, C.W. (2013): A multifactor analysis of fungal and bacterial community structure in the root microbiome of mature Populus deltoides trees. PLoS One, 8, e76382

Tamura, K., Stecher, G., Peterson, D., Filipski, A. \& Kumar, S. (2013): MEGA6: Molecular Evolutionary Genetics Analysis version 6.0. Mol. Biol. Evol., 30, 2725-2729.

Teplitski, M., Barak, J.D. \& Schneider, K.R. (2009): Human enteric pathogens in produce: un-answered ecological questions with direct implications for food safety. Curr. Opin. Biotechnol., 20, 166-171.

Tyler, H.L. \& Triplett, E.W. (2008): Plants as a habitat for beneficial and/or human pathogenic bacteria. Annu. Rev. Phytopathol., 46, 53-73.

Van Overbeek, L.S., Van Doorn, J., Wichers, J.H., Van Amerongen, A., Van Roermund, H.J. \& Willemsen, P.T. (2014): The arable ecosystem as battleground for emergence of new human pathogens. Front. Microbiol., 5, $1-17$.

Varma, J.K., Samuel, M.C., Marcus, R., Hoekstra, R.M., Medus, C., et al. (2007): Listeria monocytogenes infection from foods prepared in a commercial establishment: A case-control study of potential sources of sporadic illness in the United States. Clin. Infect. Dis., 44(4), 521-528.

Vivant, A.L., Garmyn, D. \& Piveteau, P. (2013): Listeria monocytogenes, a down-to-earth pathogen. Front. Cell. Infect. Microbiol., 3, 1-10.

Warriner, K. (2005): Pathogens in vegetables. -in: Jongen, W. (Ed.) Improving the safety of fresh fruit and vegetables. Woodhead Publ. Ltd, Cambridge, pp. 1-40.

Weisburg, W.G., Barns, S.M., Pelletier, D.A. \& Lane, D.J. (1991): 16S ribosomal DNA amplification for phylogenetic study. J. Bacteriol., 173, 697-703. 